\title{
Shrinking the Administrative State: New Public Management Before and After 9/11
}

\author{
KEITH M. HENDERSON \\ SUNY College at Buffalo, N.Y., Estados Unidos
}

\begin{abstract}
Resumen
La Nueva Administración Pública (NPM) es un fenómeno mundial que nace de la experiencia norteamericana. Alimentada en los años de la administración Reagan con la retórica de "quitarse al gobierno de las espaldas", éste maduró bajo la crítica nacional a la actuación del Presidente Clinton y el posterior acercamiento republicano bajo el mandato del Presidente Bush. Tanto los líderes demócratas como republicanos proporcionaron una visión de gobierno empresarial, menos intruso pero más responsable a los ciudadanos. El índice de crecimiento de los programas de gobierno iba a ser limitado. Sin embargo, el ataque terrorista del 11 de septiembre del 2001 sobre el World Trade Center y el Pentágono dio pie a la "guerra contra el terrorismo" cambiando las prioridades. Fueron enfatizados los valores tradicionales de la administración pública, el control y la coordinación centralizada y la cooperación intra-gubernamental. La disminución del estado administrativo fue limitado a las áreas que no implican temáticas de defensa y seguridad.
\end{abstract}

\begin{abstract}
The New Public Management (NPM) is a worldwide administrative phenomenon that is well-exemplified in the United States experience. Nurtured in the Reagan years with "get government off our backs" rhetoric, it matured under President Clinton's National Performance Review and the subsequent Republican approach under President Bush. Both the Democratic and Republican leadership provided a vision of business-like government that is less intrusive yet responsive to citizens. The rate of growth of government programs was to be curtailed. However, the September 11, 2001 terrorist attack on the World Trade Center and the Pentagon gave rise to a "War on Terror" that changed priorities. Traditional public administration values of centralized control, coordination, and inter-governmental cooperation were emphasized. Shrinking of the administrative state was limited to non-Defense, non-Homeland Security arenas.
\end{abstract}

PALABRAS CLAVE •New Public Management •Administrative Reform • Comparative Administration -National Performance Review $\bullet$ War on Terror

\section{INTRODUCTION}

Although the commonly cited New Public Management (NPM) is neither truly new, nor public in its orientation, nor primarily concerned with the nuts and bolts of management, it has achieved nearcult status as a universal reform paradigm. Sometimes confused with the New Public Administration - the younger generation's zealous late 1960s and 1970s alternative to traditionalism ${ }^{1}$ the New Public Management has very different characteristics rooted in private sector competitiveness,

1 In 1968, Dwight Waldo -doyen of the public administration academic world-called together 33 of us who were allegedly promising and undeniably young (the next generation) at the Minnowbrook Conference Center of Syracuse University. The first resulting volume (Marini, 1971) postulated a new, socially conscious philosophy of administration. 
entrepreneurialism, and customer satisfaction. NPM - and its offspring the National Performance Review in the U.S. - advocates a shrinking of the administrative state, a preference for contracting out and privatization, and the use of various deregulation, decentralization and procedural simplification measures. Stanford Borins has described the New Public Management in its personnel aspect as a normative reconceptualization consisting of several interrelated components:

1. Government should provide quality services valued by citizens.

2. Autonomy of public officials, particularly from central agency controls should be increased.

3. Evaluation and rewards should be based on how well performance targets are met.

4. Necessary human and technological resources should be available to officials.

5. The value of competition must be appreciated and an open-minded attitude toward private rather than public service provision should be maintained (Borins, 1998: 9). ${ }^{2}$

NPM has been widely analyzed and strongly criticized for its neglect of the truly public dimensions of government such as democratic and constitutional values. Nevertheless, it continues to be applied -as it was in the 1980s and 1990s- in a variety of contexts throughout the world.

An example of a country with considerable interest in the New Public Management is Chile, as shown in its Commission on Modernization of the State in the Secretariat of the President as well as previous efforts to modernize administration.

This brief paper seeks to provide an updated U.S. perspective by indicating some significant challenges to the paradigm resulting from the horrendous assault on the World Trade Center and the Pentagon on September 11, 2001 (9/II) and the political/administrative response to that assault in the form of anti-terrorism policies and actions.

First, it is necessary to explore the development of NPM - and, in particular, its Clinton era manifestation in the U.S., the National Performance Review. Then, it will be useful to note the changes in the Bush administration prior to 9/11. Finally, the "War on Terror" will be considered and its implications for the New Public Management.

\section{THE U.S. EXPERIENCE BEFORE 9/11 IN COMPARATIVE PERSPECTIVE}

The U.S. experience with the shrinking administrative state is paralleled in other Western countries and -by extension- in those areas of the world impacted by bi-lateral and multi-lateral 'structural adjustment' aid from the West or independently pursuing administrative reform. The U.S. experience -while arguably the most influential- is neither as draconian nor as widespread as in some countries. The United Kingdom, for example, extensively downsized its central administrative apparatus during the Thatcher era and continued to privatize government operations after Prime Minister Margaret Thatcher's departure; similarly, Australia and New Zealand -along with Canada- have undertaken major restructuring efforts and Scandinavian countries -notably Sweden- have also been at the forefront of reform. The New Public Management experience in Latin America -focusing on Mexico but including Chile and other countries-is documented in a study by Barragan and Roemer (2001).

2 Other good overviews are provided by Kettl and Dilulio (1995) and Barzelay (2001). 
Deregulation, decentralization, hiring freezes, sale of government assets, consolidation of programs, and other "debureaucratization" measures have been the order of the day. Constraints originating from the revenue side, which severely limited the resources available for public programs in many countries, contributed to the trend. Also important has been public perception of bureaucracy as over-intrusive.

Under Ronald Reagan - U.S. Republican president from 1980-88 and George H.W. Bush, 19881992, emphasis turned from government as a problem solver to government as part of the problem. Numerous cost-cutting and deregulation measures (air traffic, trucking, savings and loan associations, etc.) were implemented. Devolution of functions to the state government level was also pursued along with various privatizations.

\section{THE METAPHORS}

If the administrative state requires shrinking in the eyes of political leaders and the public, the assumption is that it is 'bloated' or 'thickened' (Light, 1995) and, hence, in need of corrective downsizing or "rightsizing." Metaphors abounded in the Reagan years, encouraged by a President who sought to get bureaucracy "off our backs" and identified it as over-intrusive and a drag on the economy. Bureaucrat bashing became commonplace reflecting the populist efforts first encountered in California's Proposition 13, in 1978, which restricted property taxes through citizen initiative. General disenchantment with government following the war in Vietnam, the Watergate episode, and several widely publicized scandals was exacerbated as political leaders at the State and National levels attacked the bureaucracy.

The metaphors of a bloated bureaucracy, an unwieldy Leviathan which needs to be "tamed" (Gormley, 1989), and various images borrowed from the business world, particularly the thinking of David Osborne and Ted Gaebler (1992), precipitated a movement subsequent to the Reagan-Bush years to "reinvent" and "reengineer" government by focusing on the customer, "empowering" employees, and injecting competition into service delivery. The business community had begun earlier to downsize and some $80 \%$ of the Fortune 500 companies had already done some restructuring between 1988 and 1995 (Kingbury and Weiss, 1995: 13).

\section{THE NATIONAL PERFORMANCE REVIEW}

A Democratic President -in office from 1992 through 2000- did not advocate continuity with Reagan-Bush policies, but undertook a major "reinvention" program of his own, also modeled on business practices. Under Vice President Gore, the widely discussed Reinventing Government project continued through the Clinton years and towards its conclusion Clinton and Gore could point to the elimination of 377,000 Federal government jobs, implementation of hundreds of reform initiatives, and savings to American taxpayers of $\$ 136$ billion. Such claims provoked further analysis since not all accomplishments were directly related to the NPR.

Unlike previous reform efforts such as those deriving from the Grace Commission (Arnold, 1995: 413), emphasis in the NPR was less directed toward simple budget reduction and an assault on waste, fraud and abuse (still important) and more upon "Creating a Government that Works Better 
and Costs Less" and moving "From Red Tape to Results" (National Performance Review, September 7, 1993). Total Quality Management provided some intellectual ideas along with public choice theory, but a collection of business-like precepts and anecdotes from the corporate world rather than a coherent theory was its foundation. Its basic thrust was not new but reflected thinking in management literature in relation to business enterprises. The notion of entrepreneurship had been around for several hundred years.

The Democrats' National Performance Review began on March 3, 1993, when President Clinton directed Vice President Gore to lead a six-month analysis of the federal government encompassing all Departments and operations. The goal was to identify problems and suggest solutions; each Department was expected to organize a "Reinvention Team" and create "Reinvention Laboratories" where experiments in new methods could be tested. The stress was upon how government should work not what it should do; the promise was to reduce the federal workforce by 252,000 through 1999 -or about 12\%- and towards that end the Government Performance and Results Act (GPRA) was passed in 1993 (a Congressional initiative) along with a supplementing Executive Order (12861, 9/30/93) to implement the design. Agencies were to set outcome goals, measure their performance, and report accomplishments. Agencies were further instructed to examine their program execution and to eliminate $1 / 2$ of their internal regulations within three years.

Reporting in January, 1994, after the first phase of the study, pilot projects were described for 21 departments and agencies. The pilot projects covered entire organizations (Defense Logistics Agency; Forest Service; Internal Revenue Service; Small Business Administration; Social Security Administration) and specific programs (Post-secondary Student Loan and Grant Programs; Organized Crime and Drug Program; Air Traffic Control, etc.) Periodic reports of accomplishments thereafter were upbeat and anticipated the continuation of the NPR in REGO II (Reinventing Government, second phase) or NPR II at the end of the first year. Over 60 extensive in-house studies were available as of late 1995 (National Performance Review, 1993: 4-5). These indicated that numerous changes had been implemented and many others remained under review. Some $\$ 58$ billion in savings; employment reductions ahead of schedule $(160,000)$; Congressional enactment of a new procurement strategy and 35 other NPR related measures; and agency completion of nearly $1 / 3$ of the original recommendations were all indicated in the September 1995 status report (NPR, Common Sense Government).

\section{CLINTON/GORE MEETS DOLE/GINGRICH}

The Republican conquest of the Congress in November 1994 introduced a new agenda for administrative reform which exceeded even the ambitions of the National Performance Review. Partisan considerations precluded large-scale agreement with the NPR's recommendations but did not prevent a similar targeting of the bureaucracy. The GOP "Contract with America" in the House of Representatives promised to propose in the first 100 days (at the end of which they had delivered on their promise with various proposals) a plethora of reforms including deregulation measures, budget balancing, and replacement of entitlement programs with block grants to the states. Issuing of regulations, for example, would be made considerably more difficult for federal agencies by requirements for cost-benefit analysis and risk assessment, mandate relief for states, and use of "market-based mechanisms" comparable to existing "pollution rights" which may be 
sold at auction (Wall Street Journal, March 1, 1995). Focusing more on program and tax changes than structural adjustments in the departments, the House Republican initiatives nevertheless carried numerous implications for the bureaucracy. The emphasis upon agency and program consolidations, reductions, and terminations resembled REGO II (Carroll,1995: 308). Also similar was the stress on collapsing grant programs and shifting of responsibilities to the state and local levels.

In the Senate, Majority Leader Robert Dole -presaging a bid for the Republican Presidential nomination- suggested his own reforms which included elimination of four cabinet departments. Spirited defenses by Cabinet Secretaries and allied interest groups helped to diffuse some of the Dole thrust. For example, Housing and Urban Development Secretary Henry Cisneros was able to point to his early "reinvention" efforts which involved all of his employees participating in one-day retreats, town meetings of senior political executives, and evaluation of 15,000 recommendations for change (Thompson and Jones, 1995). All these had been completed prior to November, 1994 and much self-analysis had begun in HUD even prior to the National Performance Review. HUD faced a threat not only from the newly empowered Republicans but also from advisors within the White House who had recommended its abolishment.

The Commerce Department became a serious target for elimination when House Republicans proposed (September, 1995) an elaborate and detailed design for canceling programs, transferring functions, redesigning the Office of Trade Representatives, and otherwise "consolidating" to save $\$ 6$ to $\$ 8$ billion. Although the proposal made little headway against a concerted opposition, it at least symbolized another quest for elimination of Cabinet departments.

\section{SHRINKING THE PERSONNEL}

Budget cuts, program eliminations, and even the occasional termination of an agency such as the Interstate Commerce Commission have been supplemented by the widespread closing of military bases, shuttering of regional offices in Agriculture and Housing and Urban Development, greater Congressional scrutiny of employee benefits, and outsourcing and privatization on a small scale.

An important part of the 'shrinking' has been the Voluntary Separation Incentives ('buyouts') consisting of payments of a cash incentive to encourage resignation, early retirement, and retirement of those eligible. Nearly 69,000 Department of Defense employees had taken buyouts as early as 1995 and the U.S. Postal Service - even earlier, in its major 1992 restructuring - gave buyouts to nearly 49,000 employees. Other agencies with early authority to offer voluntary separation included the CIA, GAO, and the Library of Congress. In 1994, the Federal Workforce Restructuring Act (PL 103-226) extended buyouts to nearly all employees up to a maximum of $\$ 25,000$. The law also mandated reductions in federal personnel by 272,000 by 1999 , a goal which was surpassed. In subsequent years, government wide buyout authority has been reauthorized.

The 2000 Federal budget (passed in 1999) refers to partnerships with state and local government, industry, unions, and -by implication- the non-profit sector. Congressional testimony stressed partnerships between law enforcement and private industry as well as cyber-citizenship partnerships involving internet security. 
From the start, Vice President Gore, working with the departments, agencies, inter-agency working groups, and worker representatives, and drawing on the expertise of the private sector, has led an unprecedented effort to make the Federal Government more efficient and effective while also reducing its size." (U.S. Budget, 2000: 45) 'Priority Management Objectives' (PMOs) was a key strategy.

\section{THE TRANSITION TO GEORGE W. BUSH}

A Republican administration arrived with a new agenda as George W. Bush assumed power in January, 2001. Administratively, there were allusions to pay for performance, other civil service reforms, greater management flexibility, and new accountability measures. However, the usual expressed concern with widespread administrative reform found in early days of most administrations was largely absent; no Reinvention effort, blue ribbon commission, or sweeping legislative proposals emerged. Rather, the stress was on macro-economic policy changes most notably large-scale tax reductions. A clear intention to stimulate business expansion, move the bureaucracy toward new forms of partnering (e.g. the faith-based initiative, drawing in religious organizations), and a redesign of inter-governmental relations were high on the agenda. The NPR (interestingly, in its final phase the NPR had been renamed the National Partnership for Reinventing Government) was largely ignored without being reversed but some of the other Clinton era policy positions were -in fact- reversed. Notably, environmental safeguards were rolled back along with some workplace protections. Much of this activity was in a lower level of enforcement or a reinterpretation of the rules rather than discrete policy pronouncements. Clearly, the Bush administration was going to be business-friendly and the spirit -if not the earlier language- of the New Public Management would prevail.

\section{AFTER 9/11}

9/11 was a defining moment. In administration as in the polity generally, it became necessary to realign missions, reorganize programs, and assure better coordination in intelligence and other operations. Not only was the United States affected, but all countries with a concern for terrorism on their sovereign territory were alerted to the new dangers. Cooperation was sought by the United States and various alliances, coalitions, and cooperative understandings were developed.

The immediate administrative response in the United States was to pass the "Patriot Act," easing the way for intelligence and police agents to obtain information on potential terrorist activity and detain suspect individuals. Additionally, an Office of Homeland Security was created in the Executive Office of the President and former Governor Tom Ridge was appointed director. Subsequently, a Department of Homeland Security was established (January 2003), also with Tom Ridge as chief administrator (Secretary). Twenty two previously separated agencies such as Customs, Immigration, and the Coast Guard were brought together in a single organization creating one of the largest Federal Departments and the first major Departmental reorganization in 50 years. A new superstructure established five "Directorates" under politically appointed administrators: Border and Transportation Security; Emergency Preparedness and Response; Information Analysis and Infrastructure Protection; Science and Technology; and Management. In addition, three "mission agencies" were designated: Coast Guard, U.S. Citizenship and Immigration Services (the old Immigration Service), and the U.S. Secret Service (U.S. Federal Budget 2005: 161). Public employee 
union protections were undercut as top management attained greater discretion than in the old organizations. Union efforts with Democratic Congressional support to prevent loss of hard-won job rights were largely unsuccessful in the political atmosphere of the day.

In the National Defense Authorization Act of 2004 (signed into law on November 24, 2003), similar discretion was given to the Secretary of Defense in determining how jobs are paid and contracted out, and what functions can be abolished. As with Homeland Security, there is now less oversight from Congress, the Office of Personnel Management, and the public employee unions (Federal Personnel Guide, 2004: 3).

In the 2003 U.S. Federal Budget, the Bush administration announced a grading system for federal agencies which would evaluate progress on the President's Management Agenda. The "stoplight" system (green, yellow, and red markings) was the essence of simplicity, providing "a powerful incentive for agencies to improve their internal management" (Performance and Management Assessment, Fiscal year 2004: 2). Illustrative of the continuing New Public Management thinking is the following:

Take, for example, the Department of Veterans Affairs (VA).

On September 30, 2002, VA's score in competitive sourcing was red for status and red for progress. Its early poor score was the result of VA's unwillingness to subject the commercial activities it performs to public-private competition. To improve its score, VA not only demonstrated a commitment to open up existing positions to competition, but it hired experts to jump start its competitive sourcing work. It now has a central office that coordinates and conducts training for field staff" (Performance and Management Assessment, Fiscal Year 2004: 2).

Overall, the announced purpose of the President's Management Agenda is to correct long-standing problems and improve the government's performance. Five government-wide "initiatives" are indicated, one of which is "competitive sourcing." The other four are: Strategic Management of Human Capital; Improved Financial Performance; Expanded Electronic Government; and Budget and Performance Integration.

\section{CONCLUSION}

As of early 2005, some might argue that elements of the New Public Management are alive and well in the Bush administration. On the other hand, the overwhelming concern with Homeland Security and Defense is reflected in budgetary re-alignment as functions related to those activities are rewarded while others are reduced. New administrative arrangements give more authority to top officials and coordination proceeds apace in arenas such as intelligence (a new intelligence "czar" was appointed in February, 2005). Traditional administrative precepts such as centralized control, coordination, and inter-governmental cooperation are emphasized.

A special issue of the Public Administration Review in September 2002 (Volume 62) assessed the early impact of 9/11 administratively, including appraisals of the New Public Management. In one selection, M. Shamsul Haque suggests that NPM may be superceded by a new paradigm. Echoing Gormley (2002) and others he states: 
Finally, thinking is emerging that the current shift toward a greater role and positive image of public administration may promise a new paradigm - evident in the growing appreciation and conviction of public servants, diminishing belief in private sector superiority, and enhanced cooperation among public agencies (Haque, 2002, 177).

Although some might argue that there is no contradiction between NPM (at least in the benign form indicated by Borin, on p. 2 here) and new appreciation for public employees, others will make the case that a fundamental shift in attitude has occurred. Certainly, the private sector and its competitive, entrepreneurial strategies would not seem to be the proper model for a War on Terror which involves mobilizing military and intelligence resources in the best possible manner.

A debate continues as to both the effectiveness of the post 9/11 administrative measures that have been taken and their infringement on civil liberties. Some in Political Science -such as Francis Fox Piven- are aghast that big business coupled with the populous right has hijacked the agenda (Piven, 2004). Others who are also widely quoted wonder how anyone can advocate the withering away of the state when only the state can combat terrorism (Fukuyama, 2004: 120). On the opposite side -but still among those on the lecture circuit- Newt Gingrich (architect of the 1994 'Contract with America' referred to before) in a 10 year update now argues that America is ready for a new contract built around conservative policy prescriptions. He attempts to make a case that the majority of Americans support his ideas. (Gingrich, 2004).

The New Public Management will continue to attract advocates and detractors even as it becomes further embroiled in political discussions concerning the proper scope and functions of government. A new results-oriented New Public Management may emerge in the United States without the discussion of customer satisfaction, empowerment of employees, or entrepreneurial skill but with a focus (apart from agencies involved in the security or military mission) on containing cost, shrinking personnel, and partnerships.

\section{REFERENCES}

Arnold, Peri. 1995. “Reform's Changing Role”. Public Administration Review 55 (5): 407-417.

Barragan, Esteban and Andres Roemer. 2001. A New Public Management in Mexico. Aldershot, England: Ashgate.

Barzelay, Michael. 2001. The New Public Management, Improving Research and Policy Dialogue. Berkeley: University of California Press.

Borins, Standford. 1998. Innovating with Integrity: How Local Heroes Are Transforming American Government. Washington, D.C.: Georgetown University Press.

Carroll, James. 1995. "The Rhetoric of Reform and Political Reality in the National Performance Review". Public Administration Review 55 (3): 302-312.

Federal Personnel Guide. 2004. Washington, D.C.: Key Communications Group, Inc. 3

Fukuyama, Francis. 2004. State Building, Governance and World Order in the $21^{\text {st }}$ Century. Ithaca, N.Y.: Cornell University Press. Gingrich, Newt. 2004. Winning the Future. New York: Regency.

Gormley, William. 1989. Taming the Bureaucracy, Muscles, Prayers and Other Strategies. Princeton, N.J.: Princeton University Press.

Gormley, William. 2002. "Reflections on Terrorism and Public Management". In Governance and Public Security, edited by Alasdair Roberts. Syracuse, N.Y. (Maxwell School): Syracuse University Press, 1-16.

Haque, M. Shamsul. 2002. "Government Responses to Terrorism: Critical Views of Their Impacts on People and Public Administration". Public Administration Review 62 (5): 170-179. 
Kettl, Donald and John Dilulio (eds.). 1995. Inside the Reinvention Machine: Appraising Government Reform. Washington, D.C.: Brookings.

Kingsbury, Nancy and Paul Weiss. 1995. "Introduction: Issues Unaddressed by the National Performance Review". The Public Manager. The New Bureaucrat 24(2): 7-15.

Light, Paul. 1995. Thickening Government. Washington, D.C.: Brookings.

Marini, Frank (ed.). 1971. Toward a New Public Administration. Scranton, Pa.: Chandler.

National Performance Review. 1995. Common Sense Government. Third Report of the National Performance Review. Washington, D.C.: Government Printing Office.

National Performance Review. 1993. From Red Tape to Results, Creating A Government That Works Better and Costs Less: The Report of the National Performance Review. Washington, D.C.: Government Printing Office.

National Performance Review. 1994. Creating A Government That Works Better and Costs Less: Status Report. Washington, D.C.: Government Printing Office.

Common Sense Government, Third Report of the National Performance.

Review, Vice President Al Gore. 1995.

From Red Tape to Results, Creating a Government That Works Better And Costs Less, Report (1993).

Creating a Government That Works Better and Costs Less, Status, Report (1994).

Osborne, David and Ted Gaebler. 1992. Reinventing Government, How the Entrepreneurial Spirit is Transforming the Public

Service. Reading, Mass.: Addison-Wesley.

Performance and Management Assessment Fiscal Year. 2004. Washington, D.C.: U.S. Government Printing Office.

Piven, Francis Fox. 2004. The War at Home: The Domestic Costs of Bush's Militarism. New York: New Press.

Public Administration Review. 2002. 62 (Special Issue): 1-192.

Thompson, James and Vernon Jones. 1995. "Reinventing the Federal Government: The Role of Theory in Reform Implementation". American Review of Public Administration 25(2): 183-199.

United States Federal Budget, Fiscal Year 2000.

United States Federal Budget, Fiscal Year 2005.

Wall Street Journal. 1995 (March 1). A1.

Keith M. Henderson received his D.P.A. from the University of Southern California and has done post-doctoral work at Columbia University. He is currently Professor of Political Science at the State University of New York, College at Buffalo and previously served as Associate Professor of Public Administration at the Wagner School of Public Service, New York University. He has received two Fulbright Senior Scholar grants, the most recent to Croatia where he taught in the Faculty of Law at the University of Rijeka. He has published numerous works in Public Administration including Bureaucracy and the Alternatives is World Perspective (with O.P. Dwivedi, Macmillan, 1999), and Public Administration in World Perspective (also with O.P. Dwivedi, lowa State University Press, 1990).

(E-mail: henderkm@buffalostate.edu) 